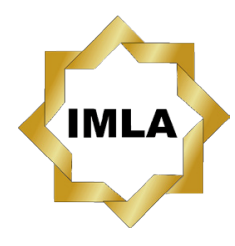

\title{
LINGKUNGAN ARTIFISIAL DALAM PEMBELAJARAN BAHASA ARAB
}

\author{
Nur Habibah \\ Universitas Islam Negeri Syarif Hidayatullah Jakarta \\ E-mail: nhabeiba@yahoo.com
}

Naskah diterima: 18 September 2016, direvisi: 12 Oktober 2016, disetujui: 20 Nopember 2016.

\begin{abstract}
This research was aimed at proving whether artificial language environment affect Arabic language skills and analyzing how the artificial language environment impact the skills. The method used in this research was categorized into a field research which combined both qualitative and quantitative method, or well-known as mixed method. The primary source in this research was taken from the 1st and 2nd grade of senior high madrasah Pondok Pesantren Madinatunnajah Jombang Ciputat, South Tangerang academic year 2015/2016. Moreover, the secondary source was obtained from some literatures in the form of academic journals and books related to this study. The research found that environment-based language learning was more effective and influential on listening, speaking, reading, and writing skills of Arabic language. It was concluded that language skills are not only determined by LAD (Language Acquisition Device), a gifted device to acquire language, but also determined by the environment the learner lived.
\end{abstract}

Keywords: Arabic language learning, artificial environment, language skills, behaviorism

\section{Abstrak}

Penelitian ini bertujuan untuk membuktikan apakah lingkungan bahasa artifisial berpengaruh terhadap kemahiran berbahasa Arab serta menganalisis bagaimana lingkungan bahasa artifisial dapat mempengaruhi kemahiran berbahasa Arab. Jenis penelitian ini adalah penelitian lapangan (field research) dengan mengombinasikan pendekatan kuantitatif dan kualitatif (Mixed Method). Sumber data primer dalam penelitian ini adalah siswa kelas 1 dan 2 Madrasah Aliyah Pondok Pesantren Madinatunnajah Jombang Ciputat, Tangerang Selatan Tahun 2015/2016. Adapun data sekunder bersumber dari literatur-literatur kepustakaan berupa jurnal akademik dan buku-buku yang selaras dengan penelitian ini. Hasil penelitian ini menyimpulkan bahwa pembelajaran bahasa Arab berbasis lingkungan lebih efektif dan berpengaruh terhadap kemahiran menyimak, berbicara, membaca dan menulis bahasa Arab. Sebab kemampuan berbahasa tidak hanya ditentukan oleh LAD (Language Acquisition Device) yang merupakan sebuah perangkat akuisisi bahasa bawaan sejak lahir, melainkan sangat dipengaruhi oleh lingkungan dimana seseorang tersebut tinggal.

Kata Kunci: pembelajaran Bahasa Arab, lingkungan artifisial, kemahiran berbahasa, behaviorisme

How to Cite: Nur Habibah. "Lingkungan Artifisial dalam Pembelajaran Bahasa Arab" Arabiyat : Jurnal Pendidikan Bahasa Arab dan Kebahasaaraban [Online], Volume 3 Number 2 (31 December 2016)

Permalink/DOI: http://dx.doi.org/10.15408/a.v3i2.4038 


\section{Pendahuluan}

Bahasa Arab menjadi salah satu bahasa asing yang telah diajarkan di hampir seluruh sekolah di Indonesia, khususnya sekolah-sekolah berbasis Islam. Pengajaran bahasa Arab telah mengalami perkembangan dari masa ke masa sesuai dengan kemajuan zaman dan teknologi.

Perkembangan teknologi sebagai media diciptakan untuk meningkatkan kemahiran berbahasa Arab siswa. Sebab keberhasilan siswa memahami kaidah, membaca dan menulis serta menerapkannya dalam komunikasi baik lisan maupun tulisan, merupakan tolok ukur bagi pengajar bahwa tujuan pembelajaran bahasa telah tercapai. Hal ini karena bahasa Arab merupakan pelajaran bahasa asing yang tidak dapat terlepas dari kesulitan-kesulitan dan problem dalam pembelajarannya. ${ }^{1}$

Sulitnya memahamkan kaidah bahasa Arab kepada siswa menjadi problem tersendiri bagi pengajar. Selain karena bahasa Arab adalah bahasa asing, problem linguistik seperti artikulasi, kosakata dan kaidah gramatika yang lebih kompleks, menyebabkan bahasa Arab menjadi salah satu bahasa asing yang cukup sulit dipahami. Selanjutnya problem non-linguistik yang datang dari pengajar seperti metode dan pendekatan yang tidak tepat, strategi pengajaran, dan minimnya penerapan media pembelajaran, akhirnya semakin menimbulkan anggapan bahwa bahasa Arab adalah pelajaran yang sulit dipahami siswa yang menyebabkan minat belajar bahasa Arab semakin rendah. ${ }^{2}$

1 Acep Hermawan, Metodologi Pembelajaran Bahasa Arab (Bandung: PT Remaja Rosdakarya, 2011), h. 99.

2 Mahmud Ali Samman, Al-Taujîh fî Tadrîs alLughah al-'Arabîyah (Kairo: Jâmi'ah ȚanṬa, 1983), 158-159. Selanjutnya Acep Hermawan, Metodologi Pembelajaran Bahasa Arab, h. 100.
Tujuan pengajaran bahasa Arab meliputi empat keterampilan berbahasa yang harus dikuasai oleh siswa yaitu: keterampilan menyimak, berbicara, membaca dan menulis (mahârat al-istimâ'; mahârat alkalâm, mahârat al-qirâ'ah, wa-mahârat al-Kitâbah) menjadi problem bagi pelajar, dimana pelajar baru dapat dikatakan mahir berbahasa Arab jika telah menguasai empat keterampilan berbahasa. ${ }^{3}$

Problem pembelajaran tersebut menurut peneliti merupakan tugas berat bagi pengajar untuk dapat menciptakan pelajaran bahasa Arab menjadi pembelajaran yang menyenangkan. Minat belajar dan motivasi siswa yang rendah kemudiandapatberubahmenjadikeinginan kuat untuk mempelajari bahasa Arab yang bukan hanya sebagai pelajaran untuk dapat memahami al-Qur'an dan Hadis sebagai pedoman umat Islam. Melainkan juga menjadikan bahasa Arab sebagai pelajaran yang dapat mengembangkan potensi pelajar dalam bidang linguistik.

MenurutJamesS. Hendrickson, problem dalam pembelajaran bahasa Arab tidak terlepas dari penggunaan metode oleh pengajar. ${ }^{4}$ Problem pembelajaran bahasa asing masih jarang diamati oleh pengajar bahasa yang menganggap bahwa metode pengajaran bahasa aktif seperti metode langsung sudah cukup bagi pelajar. Padahal menurut Rod Ellis, mempelajari bahasa sejatinya adalah untuk berkomunikasi, sehingga menggunakan bahasa sasaran

3 Acep Hermawan, Metodologi Pembelajaran Bahasa Arab, 55. Selanjutnya lihat Țaha 'Ali Husain al-Dîlamy wa Sa'ad 'Abd al-Karîm al-wâ'ily, Ittijâhât Hadîthah fî tadrîs al-Lughah al-Arabîyah (Oman: Jidâr Maktab al 'Âlamy, 2009), h. 202.

4 James S. Hendrickson, "Error Correction in Foreign Language Teaching: Recent Theory, Research, and Practice", The Modern Language Journal, Vol. 62, No. 8 (Dec., 1978), h. 387-398. Published by: Wiley, http://www.jstor.org/stable/326176. 
yang sedang dipelajari adalah cara terbaik untuk bisa berbahasa asing. ${ }^{5}$

Fatimah AbdulAzizUsman mengatakan, bahwabelajarbahasaadalahuntuklangsung praktek. Belajar bahasa bukan sekedar memahami akan tetapi agar mahir dan dapat berkomunikasi. Belajar bahasa untuk memungsikan bahasa itu sendiri, belajar bahasa adalah mempelajari konsensual antara kaidah dan konten dan belajar bahasa adalah untuk mengintegrasikan antara kemahiran-kemahiran bahasa. Menurutnya, jika cara-cara tersebut di atas diamalkan oleh pengajar bahasa, maka problem dalam pembelajaran bahasa akan terminimalisir. ${ }^{6}$

Erin Kearney juga berpendapat, bahwa dalam memberikan pengajaran bahasa kedua di dalam kelas, seorang guru hendaknya memberikan pemahaman yang tepat sebelum memberikan perintah. Kesalahan dalam memberikan metode akan menyebabkan kegagalan dalam memahami materi. Menurutnya, hal itu seperti halnya ketika guru mengajak siswa untuk berenang dalam sebuah kolam renang, namun hanya menunjukkan seperti apa bentuk kolam renang tersebut dan langsung meminta para siswa untuk berenang. Faktanya, siswa tidak mengetahui sedalam apa kolam tersebut dan bagaimana cara berenang yang baik. ${ }^{7}$

Teori ini kemudian mengundang tanggapan dari S. Alkhasawneh, F. Abd.

5 Rod Ellis, "Second Language Learning and Second Language Learners: Growth and Diversity", TESL Canada Journal/Revue TESL Du Canada, Vol. 7, No. 1, (Nov, 1989), h. 74-92.

6 Fatimah Abdul Aziz Usman, "Al-Bî’ah alTa'lîmîyah wa-al-Adâ' al-Lughawî bayn al-Naẓrîyah wa-al-TaṬbîq", Markaz al-Malik Abdullah bin 'Abd alAziz, Jâmi'at Ta'lif al-'Arabîyah li-al-'Ulum al-Mihnîyah (2014), h. 147-160.

7 Erin Kearney, "Cultural Immersion in the Foreign Language Classroom: Some Narrative Possibilities", The Modern Language Journal, Vol. 94, No. 2 (Summer 2010), h. 333.
Rahman, A. F. bin M. Ayyub, dan A. Bin M. Daud, yang menyimpulkan bahwa selain penggunaan metode yang tepat, seorang guru yang memberikan motivasi terhadap siswa akan lebih mempengaruhi kemampuan siswa dalam berbahasa. ${ }^{8}$

Beberapa teori juga menyebutkan bahwa untuk meningkatkan kemampuan bahasa asing siswa, maka guru hendaknya menggunakan metode inovasi seperti the Silent Way, Suggestopedia, Community Language Learning, the Comprehension Approach, and the Communicative Approach, dan metode langsung (direct method/ al-țrîqah al-mubâsyirah). Selain itu penggunaan Strategi Pembelajaran Bahasa (SPB), strategi membaca secara sadar dan penggunaan media juga sangat berpengaruh terhadap kemampuan berbahasa kedua siswa (L2). ${ }^{9}$

Teori-teori di atas kemudian dibantah oleh beberapa pakar linguis yang menyatakan bahwa penggunaan metode inovasi, dan strategi dalam pembelajaran bahasa masih belum mempengaruhi kemampuan berbahasa kedua siswa (L2). Seperti Frank B. Vecchio yang menyatakan, bahwa penggunaan metode

${ }^{8}$ S. Alkhasawneh, F. Abd. Rahman, A. F. bin M. Ayyub, dan A. Bin M. Daud, "The Effect of Arabic as FirstLanguage Web Based Teaching in Jordanian Basic School Student's Arabic Reading Comprehension Motivation", International Journal of Innovative Ideas (IJII) ISSN: 2232-1932, Vol. 12, No. 4 (Nov., 2012), h. 20-31.

9 Lihat Diane Larsen, "Recent Innovations in Language Teaching Methodology", Annals of the American Academy of Political and Social Science, Vol. 490, Foreign Language Instruction: A National Agenda (Mar., 1987), h. 51-69. Published by: Sage Publications, http://www.jstor.org/stable/1045235. Selanjutnya lihat Madeline Kovach, "An Active Language Teaching Method", The German Quarterly, Vol. 36, No. 3 (May, 1963), h. 279-286. Kamarul Shukri Mat Teh dan Mohamed Amin Embi, "The Correlation between Language Learning Strategies and Motivation in Arabic Language Learning", Jurnal Pendidik dan Pendidikan, Jil. 24 (2010), h. 109-123. 
inovasi, media, kurikulum, dan sebagainya dalam pembelajaran bahasa hanya diberikan kepada siswa tanpa mengetahui permasalahan yang mereka hadapi, seperti peningkatan kemampuan siswa dalam berbahasa. Menurutnya, penggunaan metode serta media hanya memudahkan pengajar untuk menyampaikan materi kepada siswa, sedangkan pemahaman siswa akan terbatas pada materi dan bukan pada penerapannya, karena ketika keluar dari kelas materi yang diberikan kepada siswa tidak lantas diterapkan di luar kelas sehingga kemampuan siswa akan terbatas tanpa adanya implementasi langsung. ${ }^{10}$

Stephen D. Krasen selanjutnya menyatakan bahwa penerapan lingkungan bahasa dalam pembelajaran bahasa akan lebih efektif daripada hanya menggunakan metode inovasi. Menurutnya, lingkungan sangat berpengaruh terhadap kemampuan berbahasa anak, seperti lingkungan formal dan informal. Lingkungan memberikan pengaruh langsung terhadap pelajar dalam menerapkan teori yang dipelajarinya ketika di kelas. ${ }^{11}$

Edward Sapir juga menyatakan hal yang sama, bahwa lingkungan memiliki pengaruh besar terhadap kemampuan berbahasa anak. Selain karena menerapkan teori secara langsung, lingkungan merupakan wadah bagi pelajar bahasa untuk langsung mengucapkan apa yang dipelajarinya, sehingga tujuan

\footnotetext{
${ }^{10}$ Frank B. Vecchio, "The "Revolution" in Foreign Language Teaching", Improving College and University Teaching, Vol. 21, No. 2, Teaching the Humanities: Rose Windows of Academia (Spring, 1973), h. 147149. Published by: Taylor \& Francis, Ltd. http:// www.jstor.org/stable/27564522.

11 Stephen D. Krasen, "Formal and Informal Linguistic Environments in Language Acquisition and Language Learning", TESOL Quarterly, Vol. 10, No. 2 (Jun., 1976), h. 157-168. Published by: Teachers of English to Speakers of Other Languages, Inc. (TESOL), http://www.jstor.org/stable/3585637.
}

pembelajaran bahasa yaitu untuk berkomunikasi dapat tercapai. ${ }^{12}$

Muhammad Zaid Ismail kemudian menambahkan bahwa untuk mengembangkan kemampuan berbahasa anak maka seorang pengajar semestinya menerapkan dua bahasa sekaligus dalam pembelajarannya, yaitu menggunakan bahasa ibu serta menggunakan bahasa sasaran yang sedang dipelajari pada semua mata pelajaran di sekolah. Metode ini dikenal dengan program imersi (Immersion Program) dalam pembelajaran bahasa kedua yang ditemukan pertama kali di Kanada pada 1960-an dan telah diterapkan di beberapa sekolah di luar negeri seperti di Amerika hingga saat ini. ${ }^{13}$

Pembelajaran bahasa melalui lingkungan juga disetujui oleh Carol A. Chapelle, seperti: menginterpretasikan pembelajaran bahasa baru melalui lingkungan, mengubah konteks dalam pembelajaran bahasa, meningkatkan pengajaran dan pembelajaran, memperkenalkan budaya dalam pembelajaran dan menggunakan media baru, memberikan pengaruh yang lebih besar dalam pemerolehan bahasa kedua. Pembelajaran bahasa melalui lingkungan menurut Carol tidak hanya berada di dalam kelas, akan tetapi pembelajaran bahasa melalui lingkungan di luar kelas akan lebih meningkatkan kemampuan berbahasa anak karena kesempatan yang digunakan untuk berlatih bagi siswa lebih besar. ${ }^{14}$

${ }^{12}$ Edward Sapir, "Language and Environment", American Anthropologist, New Series, Vol. 14, No. 2 (Apr. - Jun., 1912), h. 226-242. Published by: Wiley, http://www.jstor.org/stable/659930.

13 Muhammad Zaid Ismail dan Daud Ismail, "Barnâmij al-Anghamâs (Immersion) Lughawîy fî Tahsîn al-Mahârât al-Lughawîyah”, Prosiding Seminar Pengajaran dan Pembelajaran Bahasa Arab, alJâmi'ah al SulṬ̂n Zainal Ẩbidîn Trengganu, 2014, h. 1-8.

${ }^{14}$ Carol A. Chapelle, "The Relationship between Second Language Acquisition Theory and Computer- 
Pembelajaran bahasa berbasis lingkungan yang dinyatakan oleh beberapa linguis di atas, sesuai dengan teori behaviorisme B.F Skinner bahwa untuk dapat berbahasa, seorang anak memerlukan pembelajaran berbasis lingkungan dan orang-orang yang berada di lingkungan tersebut. Teori ini dikenal dengan Stimulus-Respon-Penguatan S-R-R (stimulus-respon-reinforcement) dari sebuah pembiasaan (operant conditioning) yang dilakukan berulang-ulang. Skinner percaya bahwa lingkungan dan sebuah kebiasaan mampu memengaruhi kemampuan seseorang dalam berbahasa. ${ }^{15}$

Teori behaviorisme Skinner tersebut sesuai dengan pembelajaran bahasa asing yang memerlukan pengulangan dan pembiasaan dalam berbahasa baik lisan maupun tulisan. Baik dalam pemerolehan maupun pembelajaran bahasa, Skinner meyakini bahwa lingkunganlah yang membentuk bahasa seseorang. ${ }^{16}$

Teoripemerolehan bahasaBehaviorisme B.F Skinner kemudian ditentang oleh Noam Chomsky yang menyatakan bahwa, seseorang yang berbahasa bukan disebabkan oleh lingkungan di mana ia

Assisted Language Learning", The Modern Language Journal, Vol. 93, (2009), h. 741-753. Published by: Wiley. http://www.jstor.org/stable/2561227.

15 Burrhus Frederic Skinner merupakan ahli psikologi Amerika yang dikenal sebagai tokoh utama aliran Behaviorisme yang lahir pada 20 Maret 1904 di Pennsylvania dan wafat pada 18 Agustus 1990 atau tepatnya 10 hari setelah menerima penghargaan dari the American Psychological Association karena menderita Leukimia. Skinner telah menulis lebih dari 200 karya dalam bentuk jurnal dan buku. Lihat lebih lanjut di John A. Nevin, "Burrhus Frederic Skinner: 1904-1990", The American Journal of Psychology, Vol. 105, No. 4, (Winter, 1992), h. 613-619.

${ }^{16}$ Lihat John A. Nevin, "Burrhus Frederic Skinner: 1904-1990", The American Journal of Psychology, Vol. 105, No. 4, (Winter, 1992), 613-619. Lihat juga Nayef Khirma wa 'Ali Hijaj, al Lughât al-Ajnabîyah: Ta'lîmuhâ wa Ta'allumuhâ (Kuwait: 'Âlim al Ma'rifah, 1988), h. 15. tinggal melainkan karena setiap manusia telah dibekali sebuah perangkat akusisi bahasa atau LAD (Language Acquisition Device) yang dibawa sejak lahir. Perangkat tersebut merupakan anugerah dari sang pencipta yang memungkinkan manusia untuk berbicara dan menghasilkan ujaran yang tersusun dan dapat dipahami. LAD ini menerima "ucapan-ucapan" dan data-data lain yang berkaitan melalui panca indera sebagai masukan dan membentuk rumusrumus linguistik. ${ }^{17}$

Teori nativisme Chomsky lahir sebagai bantahan dariteoribehaviorismeB.FSkinner yang menyatakan, bahwa bahasa diperoleh melalui sebuah proses pembelajaran dan lingkungan. Teori nativisme juga disetujui oleh D. Kimbrough Oller, yang sependapat dengan Chomsky bahwa kemampuan berbahasa merupakan bawaan sejak lahir. Susunan bahasa (grammar) tidak perlu diajarkan kepada anak yang akan belajar berbahasa, karena LAD tersebut telah ada dan tersusun secara biologis sehingga secara otomatis seorang anak yang lahir akan dapat berbahasa tanpa pengajaran atau melalui lingkungan tempat ia tinggal. ${ }^{18}$

Kuniyoshi L. Sakai juga berpendapat, bahwa perangkat akuisisi bahasa (LAD) yang ada dalam otak kita akan memberikan pengaruh terhadap pemerolehan bahasa sejak pertama kali berujar. Kemudian struktur tersebut akan memberikan pengaruh pada kemampuan berbahasa kedua(L2) yaitu pada kemampuan berbicara

\footnotetext{
${ }^{17}$ Lihat Noam Chomsky, On Nature and Language (Cambridge: University Press, 2002), 61. Selanjutnya lihat Abdul Chaer, Psikolinguistik Kajian Teoritik, h. 108-109.

${ }^{18}$ D. Kimbrough Oller, "Noam Chomsky's Role in Biological Theory: A Mixed Legacy" Konrad Lorenz Institute for Evaluation and Cognition Research, Vol. 3, No. 4, (August, 2008), h. 344-350. Lihat juga Herman Parret, "Noam Chomsky. Linguistics and Philosophy by F. Hiorth", Tijdschrift voor Filosofie, 38ste Jaarg., Nr. 2 (Juni 1976), h. 319.
} 
dan menulis. ${ }^{19}$

Kemampuan berbahasa yang dianugerahkan oleh Allah melalui perangkat akuisisi bahasa (LAD) memang berpengaruh terhadap kemampuan seseorang dalam berbahasa. Namun pembiasaan dan pengulangan melalui lngkungan seperti yang diungkapkan oleh Skinner, merupakan cara terbaik dalam membentuk karakter seseorang seperti halnya dalam pembelajaran bahasa asing. Pengulangan yang dilakukan secara efektif memberikan pengaruh yang signifikan terhadap pelajar.

Lingkungan tempat seseorang tinggal secara otomatis akan memberikan masukan bahasa secara natural dengan mendengar, melihat, kemudian mengungkapkan kalimatkalimattersebutsecaraberulang-ulang. Oleh karena itu, menurut penulis, kemampuan berbahasa bukan hanya dipengaruhi oleh LAD melainkan juga berdasarkan pada kebiasaan dan pengulangan dalam sebuah lingkungan.

Seorang anak yang memiliki perangkat pemerolehan bahasa (LAD) tidak dapat dijamin akan mampu berbahasa asing tanpa sebuah lingkungan. Lingkungan memiliki pengaruh besar terhadap perkembangan seorang anak dalam berbahasa, sehingga penggunaan metode inovasi the Silent Way, direct method dan Suggestopedia serta memberikan motivasi merupakan pendukung dan cara bagi guru untuk menyampaikan materi bagi siswa ketika di kelas, namun lingkungan memiliki pengaruh lebih penting dalam pembelajaran bahasa kedua maupun bahasa asing. ${ }^{20}$

${ }^{19}$ Kuniyoshi L. Sakai, "Language Acquisition and Brain Development", Science, New Series, Vol. 310, No. 5749, System-Level Brain Development (Nov,. 4, 2005), h. 815-819.

20 Masri'ah, “Bî'ah 'Arabîyah: Pembentukan dan Peranannya dalam Pembelajaran Bahasa Arab", El-Ibtikar, Vol. 02, No. 02 (Des., 2013), h. 49-73.

\section{Pembelajaran Bahasa Arab}

Bahasa merupakan sebuah sistem kompleks dalam diri manusia dan simbol yang bersifat arbitrer yang berfungsi untuk mengekspresikan pikiran dan perasaan. Bahasa juga diartikan sebagai sebuah sistem lambang bunyi yang digunakan oleh sekelompok anggota masyarakat untuk berkomunikasi. ${ }^{21}$

Penafsiran tentang bahasa memiliki ragam pengertian, namun secara umum bahasa dapat diartikan sebagai sebuah sistem yang digunakan sebagai alat komunikasi baik secara lisan maupun tulisan untuk menyampaikan ungkapan dan pesan kepada orang lain. ${ }^{22}$

Nick C. Ellis menyatakan bahwa bahasa adalah sistem dinamis yang terdiri dari interaksi ekologis banyak pemeran yaitu orang yang berkomunikasi dan dunia yang dibicarakan. Bahasa dipengaruhi oleh banyak peran seperti: neuron, otak, dan tubuh, kemudian fonem, morfem, leksem, konstruksi, interaksi, dan wacana, selanjutnya konglomerasi manusia yang berbeda seperti individu, kelompok sosial, jaringan, dan budaya serta rentang waktu yang berbeda. ${ }^{23}$

Bahasa yang digunakan oleh setiap orang sebenarnya merupakan sebuah sistem yang tidak dapat terlepas antara

21 Abdul Chaer, Psikolinguistik Kajian Teoritik (Jakarta: Rineka Cipta, 2009), h. 30. Lihat selanjutnya Clay Beckner, Richard Blythe, Joan Bybee, Morten H. Christiansen, William Croft, Nick C. Ellis, John Holland, Jinyun Ke, Diane Larsen-Freeman, Tom Schoenemann, "Language Is a Complex Adaptive System: Position Paper", Language Learning, 59: Suppl. 1, (December, 2009), h. 1.

${ }^{22}$ Abdul Aziz Abdul Majid, Al-Lughatal-Arabîyah: Ușûluhâ al-Nafsîyah wa-Țruq Tadrîsihâ (Cairo: Dâr al-Ma'ârif, 1961), h. 17.

23 Nick C. Ellis, "The Dynamics of Second Language Emergence: Cycles of Language Use, Language Change, and Language Acquisition", The Modern Language Journal, Vol. 92, No. 2 (Summer, 2008), h. 232-249. 
satu dengan lainnya. Bahasa tumbuh sesuai dengan penggunanya di masyarakat, di mana bahasa yang digunakan antar golongan masyarakat memiliki ciri dan khas masing-masing. Perbedaan ciri dan khas bahasa dari setiap daerah tersebut yang menjadikan bahasa memiliki sifat arbitrer artinya bahasa bersifat semenamena atau sesuka hati yang tidak memiliki hubungan wajib dengan konsep yang dilambangkannya. ${ }^{24}$

Bahasa telah diperoleh sejak lahir, pemerolehan bahasa (iktisâb al-lughah) adalah periode di mana seseorang pertama kali berbahasa. Bahasa yang pertama kali diperoleh oleh seseorang adalah bahasa di mana ia tinggal, artinya bahasa pertama adalah bahasa yang digunakan oleh orang tua serta orang-orang yang berada dalam lingkungannya. ${ }^{25}$

Berbeda dengan pemerolehan bahasa, pembelajaran bahasa (ta'lîmîyah al-lughah) memiliki pengertian berbeda dengan pemerolehan bahasa (iktisâb al al-lughah). Jika pemerolehan bahasa identik dengan bahasa yang pertama kali diperoleh oleh seseorang, maka pembelajaran adalah proses yang dilakukan secara sadar dan sengaja dengan bimbingan guru atau orang di sekitar. Oleh karena itu, pemerolehan bahasa dikaitkan dengan bahasa pertama (B1) atau bahasa ibu dan pembelajaran bahasa dikaitkan dengan bahasa kedua (B2) dan atau bahasa asing. ${ }^{26}$

${ }^{24}$ Abdul Chaer, Psikolinguistik Kajian Teoritik, h. 30-31. Lihat juga Gerhard Jager and Robert van Rooij, "Language Structure: Psychological and Social Constraints", Synthese, Vol. 159, No. 1 (Nov., 2007), h. 99-130.

25 Susan Malone, "Theories and Research of Second Language Acquisition", SIL International MLE WS, (Bangkok, 2012).

${ }^{26}$ Abdul Chaer, Psikolinguistik Kajian Teoritik, (Jakarta: Rineka Cipta, 2003), h. 167, dan Theresia Kristianty, "Pandangan-Pandangan Teoritis Kaum Behaviorismetentang Pemerolehan Bahasa Pertama",
Pembelajaran bahasa menurut Rod Ellis terbagi pada dua tipe, yaitu tipe naturalistik dan tipe formal. Tipe naturalistik adalah pembelajaran bahasa yang bersifat alamiah, tanpa guru dan tanpa kesengajaan. Tipe naturalistik banyak dijumpai pada masyarakat bilingual dan multilingual, misalnya seorang anak yang menggunakan B1 dengan bahasa Jawa bersama orang tua dan keluarganya di rumah kemudian begitu keluar dan bertemu dengan temantemannya yang berbahasa Sunda maka anak tersebut secara otomatis akan mengikuti bahasa yang digunakan oleh orang-orang di lingkungannya, sehingga tanpa disadari keadaan lingkungan yang berbahasa Sunda akan memaksa anak tersebut untuk mempelajari dan menggunakan bahasa Sunda meskipun bahasa pertamanya adalah bahasa Jawa. ${ }^{27}$

Tipe kedua adalah tipe formal yang berlangsung di dalam kelas dengan bimbingan guru, materi, dan media pembelajaran. Tipe formal identik dengan proses pembelajaran di kelas yang dilakukan secara sistematis. Tipe formal berkaitan dengan pembelajaran bahasa asing dalam suatu lembaga yang memiliki tujuan pembelajaran yang telah tersusun secara sistematis dan jelas serta dilengkapi dengan beberapa indikator-indikator pencapaian. Oleh karena itu, tipe formal merupakan sistem pembelajaran bahasa yang telah terukur dan memiliki rancangan pembelajaran yang jelas dan terarah. ${ }^{28}$

Survey membuktikan bahwa bahasa Arab merupakan salah satu mata pelajaran yang membosankan dan sulit dipahami. Jurnal Pendidikan Penabur, No.06, Th.V, (Juni, 2006), h. 28.

27 Rod Ellis, Understanding Second Language Acquisition (New York: Oxford University Press, 1985), h. 215.

28 Rod Ellis, Understanding Second Language Acquisition, 215-216. 
Selain karena metode yang digunakan oleh guru tidak variatif, media dalam pembelajaran bahasa Arab juga kurang diperhatikan oleh lembaga pendidikan. Akhirnya, materi yang diampaikan oleh guru tidak sampai kepada siswa dan kemudian timbul sebuah pemikiran bahwa bahasa Arab adalah pelajaran yang sulit. Fenomena ini menyebabkan pembelajaran bahasa Arab belum mengalami kemajuan yang signifikan dalam kurun waktu yang lama sejak bahasa Arab menjadi salah satu mata pelajaran yang masuk dalam kurikulum di Indonesia. ${ }^{29}$

MenurutAbdulHusein Ahmadal-Khafaji, problem dalam pembelajaran bahasa Arab salah satunya disebabkan oleh sulitnya memahami kaidah bahasa Arab khususnya dalam ilmu Nahwu. Selain karena sulit memahami materi, metode yang disajikan oleh guru juga tidak menarik, sehingga semakin menyebabkan rendahnya minat siswa pada pelajaran bahasa Arab. ${ }^{30}$

Kata "sulit" dalam belajar bahasa Arab menurut Ahmad Țalâl Hasan dan Maheram Ahmad dalam penelitiannya yang dilakukan di Universitas Clinton Malaysia bagi siswa non muslim, adalah disebabkan karena ketidakmengertian mereka atas sifat dan realitas bahasa Arab. Menurutnya, kata "sulit" diciptakan sendiri oleh mereka yang menganggap bahasa Arab sulit.

29 Nandang Sarip Hidayat, "Problematika Pembelajaran Bahasa Arab" Jurnal Pemikiran Islam, Fakultas Tarbiyah dan Keguruan UIN SUSKA Riau, Vol. 37, No. 1 (januari-juni, 2012), 82-87. Lihat juga Suharno dan Titin Fatimah, "Problematika Metodologis Sistem Pembelajaran Bahasa Arab di Pondok Pesantren Modern Al-Istiqamah (PPMI) Ngatabaru", Istiqra', Jurnal Penelitian Ilmiah, P3M STAIN Datokarama Palu, Vol. 1, No. 2, (Juli-Des., 2013), h. 167-175.

30 Abdul Husein Ahmad al-Khifaji, "Athar Anmûdhaj 'Araḍ Mauḍ̂u' Aqsâm al-Fi'l fî̀ Tahṣ̣̂l Talâmidhat al-Șaf al-Khâmis al-Ibtidâ'î fî Mâddah Qawâ'id al-Lughah al-Arabîyah", Majallat al-Fath, Kullîyat al-Tarbîyah al-Islâmîyah Jâmi'ah Diyâli, al'Adad 54, 2013, h. 172-195.
Belajar bahasa Arab sama seperti belajar bahasa asing lain yang baru dipelajari, sehingga tidak ada perbedaan spesifik yang menyebabkan bahasa Arab lebih sulit untuk dipelajari dibandingkan dengan bahasa asing lain jika pelajar bahasa tersebut memahami sifat dan realitas bahasa yang sedang ia pelajari. ${ }^{31}$

Problem dalam pembelajaran bahasa tersebut terlihat jelas dari seluruh siswa yang telah menyelesaikan studinya, sangat sedikit dari mereka yang mampu berbahasa Arab. Daniel T. Skinner menyatakan bahwa pembelajaran bahasa yang baik adalah pembelajaran bahasa yang menerapkan langsung bahasa yang sedang dipelajari. Pengajar bahasa sebaiknya tidak memberikan tata bahasa lebih banyak daripada penggunaan bahasa itu sendiri. Menurut Daniel, belajar bahasa yang hanya menekankan pada pemahaman kaidah dan tata bahasa hanya akan membuangbuang waktu dan tenaga sebab siswa tetap tidak akan dapat berbahasa tanpa sebuah keharusan untuk berkomunikasi dengan menggunakan bahasa yang sedang dipelajari tersebut. $^{32}$

Gertrude Hildreth juga menyatakan bahwa jika seseorang mempelajari bahasa baru, maka artinya ia juga mengajak lidahnya untuk belajar dengan cara berlatih berbicara. Belajar bahasa adalah belajar menggunakan bahasa sasaran yang sedang dipelajari dengan berkomunikasi. Seperti halnya dengan pemerolehan bahasa pertama pada seorang anak yang

${ }^{31}$ Ahmad Țalâl Hasan wa Maheram Ahmad, “Ta'lîm al-Lughah al-'Arabîyah al-Tawâṣilîyah li-alTullâb ghair al-Muslimîn fî Jâmi'ah Mâlîziyâ Klintan: al-Tajârib wa-al-Tahndiyât", Prosiding Seminar Antarabangsa Pengajaran Bahasa Arab, Fakulti Pengajian Islam, Universiti Kebangsaan Malaysia (2011), h. 12-14.

${ }^{32}$ Daniel T. Skinner, "The Learning of Languages", The Modern Language Journal, Vol. 30, No. 8 (Dec., 1946), h. 594-597. 
sama sekali tidak mengetahui kaidah bahasa yang sedang ia bicarakan, ia hanya mendengar kemudian ia mengucapkan sehingga ia dapat berkomunikasi dengan sesama teman dan juga keluarganya. Belajar bahasa dengan mendengar dan menyimak seperti menghadirkan film-film atau mendengarkan berita maupun musik berbahasa asing lebih baik daripada hanya memberikan kaidah bahasa namun tidak memberikan kesempatan kepada pelajar untuk menerapkannnya dengan langsung berbicara. $^{33}$

Kesalahan tersebut menurut Ahmad Sholihuddin disebabkan kurangnya strategi pembelajaran bahasa Arab yang diarahkan pada kemampuan berbicara. Pembelajaran bahasa Arab menurutnyaharus menekankan pada kemampuan berbicara meskipun kemampuan menulis dan membaca juga sangat penting. ${ }^{34}$ Catherine E. Snow juga menyatakan bahwa apa yang diucapkan oleh anak saat belajar berbahasa adalah apa yang ia dengar dari lingkungannya seperti halnya saat anak memperoleh bahasa pertamanya. Untuk menciptakan budaya berbahasa bagi pelajar, pengajar bahasa harus membiasakan diri untuk berkomunikasi kepada peserta didik dengan menggunakan bahasa sasaran yang sedang dipelajari. ${ }^{35}$

Menurut Larisa Nikitina bahwa pembelajaran bahasa asing melalui sebuah lingkungan akan menjadi lebih nyata sebab siswa akan diajak berinteraksi langsung dengan sesama teman dan guru menggunakan bahasa asing yang sedang

33 Gertrude Hildreth, "Learning a Foreign Language”, The French Review, Vol. 31, No. 4 (Feb., 1958), h. 307-316.

${ }^{34}$ Ahmad Sholihuddin, Belajar Bahasa Melalui Kesalahan Berbahasa (Kediri: STAIN Kediri Press, 2012), h. 1-8.

35 Catherine E. Snow, “Mothers' Speech to Children Learning Language", Child Development, Vol. 43, No. 2 (Jun., 1972), h. 549-565. dipelajari. Berbahasa secara langsung melalui lingkungan akan lebih efektif jika didukung media audio visual berupa video bergambar berbahasa asing sehingga siswa akan terbiasa dengan melihat, mendengar, dan berbicara. ${ }^{36}$

Lingkungan adalah sesuatu yang ada di alam sekitar yang memiliki makna dan pengaruhtertentukepadaindividu. ${ }^{37}$ Adapun lingkungan bahasa adalah keseluruhan kondisi yang memungkinkan pelajar bahasa untuk mendengar dan melihat masukan bahasa yang sedang dipelajari. Lingkungan bahasa terbagi menjadi dua yaitu lingkungan natural dan lingkungan artifisial, dan dalam pembelajaran bahasa lingkungan bahasa terbagi pada lingkungan formal dan lingkungan informal. ${ }^{38}$

Lingkungan natural atau alamiah adalah lingkungan bahasa itu sendiri dalam bantuk alamiah di mana masyarakat penuturnya menggunakan bahasa yang sama sebagai alat untuk berkomunikasi. Lingkungan natural bisa dijumpai di pasar, di rumah, di sekolah dan di sepanjang jalan. ${ }^{39}$

Bahasa Arab yang digunakan oleh orang Arab merupakan bahasa dalam lingkungan natural karena bahasa Arab bagi orang Arab merupakan bahasa resmi dan bisa dikatakan sebagai bahasa ibu. Berbeda bagi orang Indonesia yang merupakan bahasa asing, untuk mendapatkan lingkungan alamiah, orang Indonesia yang ingin berbahasa Arab harus ke negeri Arab.

Mendapatkan lingkungan natural bagi

36 Larisa Nikitina, "Creating an Authentic Learning Environment in the Foreign Language Classroom", International Journal of Instruction, Vol.4, No.1, (January 2011), h.

37 Oemar Hamalik, Proses Belajar Mengajar (Jakarta: Bumi Aksara, 2005), h. 195.

${ }^{38}$ Heidi Dulay, Marina Burt and Stephen Krashen, Language Two (New York: Oxford University Press, 1982), h. 13.

39 Iskandarwassid dan Dadang, Strategi Pembelajaran Bahasa, h. 106. 
masyarakat Indonesia untuk belajar bahasa Arab merupakan salah satu problem nyata yang sulit diatasi. Namun mengirim pelajar ke luar negeri tidak dapat dilakukan dengan mudah, selain karena mempelajari bahasa Arab bukan suatu kewajiban bagi pelajar Indonesia, hal-hal lain seperti biaya dan jarak yang jauh akhirnya menyurutkan niat untuk dapat mendapatkan lingkungan bahasa Arab alamiah.

Alternatifnya adalah dengan menciptakan lingkungan bahasa buatan (artfisial). Lingkungan bahasa artifisial (buatan) adalah lingkungan bahasa buatan yang sengaja diciptakan untuk memberikan wadah kepada pembelajar bahasa untuk berkomunikasi menggunakan bahasa sasaran yang sedang dipelajari. Lingkungan bahasa artifisial bersifat rekayasa namun menyerupai lingkungan asli. Penerapan lingkungan bahasa artifisial adalah suatu alternatif atas ketidakmungkinan memperoleh lingkungan natural dalam pembelajaran bahasa asing. ${ }^{40}$

Menciptakanlingkunganbahasaartifisial (buatan) bukan perkara mudah jika tidak benar-benar ingin dilakukan dengan serius. Namun, jika lingkungan bahasa buatan dapat dilaksanakan dengan baik, maka tidak menutup kemungkinan para pelajar bahasa asing akan dapat berbicara layaknya penutur bahasa asli. Seperti yang diungkapkan oleh Insup Taylor, bahwa pemerolehan bahasa dipengaruhi oleh tiga variabel penting, yaitu: bahasa yang diperoleh, anak yang memperoleh bahasa dan lingkungan tempat bahasa itu diperoleh. ${ }^{41}$

SelanjutnyamenurutAbdulChaer,bahwa keberhasilan dalam bahasa, di samping ditentukan oleh sejumlah variabel, yaitu:

${ }^{40}$ Heidi Dulay, Language Two, h. 13.

${ }^{41}$ Insup Taylor, Psycholinguistiks: Learning and Using Language (Englewood Cliffts: Prentice-Hall. Inc. 1990), h. 230. murid atau pelajar, guru, bahan ajar, tujuan pembelajaran, juga sangat dipengaruhi oleh faktor lingkungan. Lingkungan bahasa berpengaruh bagi pelajar bahasa sebab bahasa bukan hanya produk individu secara personal, melainkan produk sosial secara komunal di mana setiap individu tumbuh dan menyerap kebahasaan dalam komunitasnya dengan cara belajar dan meniru. ${ }^{42}$

Kemahiran berbahasa seseorang dipengaruhi oleh beberapa faktor, di antaranya adalah faktor lingkungan dan faktor genetik berupa perangkat bahasa yang telah dibawa sejak lahir (LAD).$^{43}$ Namun peneliti menyimpulkan bahwa kemahiran berbahasa seseorang sangat dipengaruhi oleh lingkungannya. Hal ini dibuktikandenganmelakukan risetlapangan (field research) di pondok pesantren Madinatunnajah, Jombang, Ciputat, Tangerang Selatan dengan menggabungkan metode penelitian kuantitatif dan kualitatif (mixed method) untuk mendapatkan data yang lebih komprehensif.

Penelitian ini melibatkan siswa kelas $\mathrm{X}$ dan XI sebagai responden dengan menyebarkan angket kepada 78 responden dari 90 populasi atau sekitar $87 \%$. Responden dalam penelitian telah dapat dikatakan reliabel dan memenuhi syarat jika lebih tinggi dari 50,0\%. Sampel yang digunakan oleh peneliti adalah sampel acak (random sampling), artinya responden yang dijadikan sampel dalam populasi tidak berdasarkan prestasi, usia ataupun latar belakang pendidikan.

Teknik pengumpulan data dalam penelitian ini menggunakan observasi

42 Abdul Chaer dan Agustina, Sosiolinguistik Perkenalan Awal, 204, dan 'Abd al-Wâhid Wâfi, AlLughah wa al-Mujtama' (Kairo: Dâr Nahdat Mișr, 1971), h. 4.

43 Ahmad Fuad Effendy, Metodologi Pengajaran Bahasa Arab (Malang: Misykat, 2005), h. 102 . 
langsung (partisipasi aktif), melakukan wawancara kepada kepala sekolah, guru bahasa Arab dan santri pondok pesantren ini serta melakukan dokumentasi. Penelitian ini terdiri dari dua variabel, yaitu variabel $\mathrm{X}$ (Lingkungan Artifisial) dan variabel $\mathrm{Y}$ (Kemahiran Berbahasa Arab).

Kemahiran berbahasa yang diuji terdiri dari kemahiran menyimak, berbicara, membaca dan menulis. Data X diperoleh berdasarkan hasil angket yang disebarkan kepada responden dan data Y diperoleh berdasarkan hasil tes yang dibagikan kepada siswa kelas X dan XI sebagai responden. Tes yang dibagikan telah disesuaikan dengan masing-masing keterampilan, yaitu keterampilan menyimak, berbicara, membaca dan menulis.

\section{Lingkungan Artifisial dalam Pembelajaran Bahasa Arab di Madinatunnajah}

Pesantren Madinatunnajah merupakan pesantren modern yang berlokasi di Jombang-Ciputat, Tangerang Selatan yang berdiri di atas lahan sekitar 2,5 hektar milik seorang kyai bernama Drs. KH Mahrus Amin. Proses belajar mengajar yang diterapkan di pesantren ini tidak jauh berbeda dengan sekolah pada umumnya. Selain mengajarkan ilmu-ilmu agama dan bahasa Arab, pesantren ini juga mengajarkan ilmu-ilmu umum dan sains kepada seluruh santri.

Hal inidilakukan selain karena pesantren ini mengacu pada kurikulum pemerintah, juga merupakan cara agar santri tidak hanya paham dengan ilmu-ilmu agama dan bahasa Arab melainkan juga "melek" dengan perkembangan sains dan teknologi. ${ }^{44}$

Pembelajaran bahasa Arab di pesantren ini terbagi kepada beberapa cabang ilmu, di

44 Berdasarkan hasil observasi peneliti di Pondok Pesantren Madinatunnajah Jombang-Ciputat, Tangerang Selatan, pada 30 September 2016. antaranya adalah: Nahwwu, Șaraf, Mahfûzât, MuṬ̂la'ah, Balâghah, Inshâ' dan Imlâ'. Pengajar bahasa Arab di pesantren ini dan berbagai cabang ilmu tersebut merupakan pengajar yang profesional dan tidak hanya berasal dari Indonesia, melainkan juga dari Mesir, Cairo dan merupakan lulusan pesantren modern Gontor dan Timur Tengah.

Menurut ustadzah Masyitah, guru di pesantren ini bahwa, "santri di sini benarbenar diajak untuk disiplin dalam berbahasa. Kegiatan-kegiatan yang dilakukan di pesantren juga menjadi pendukung untuk santri mahir yaitu diantaranya kegiatan muhâdathah (latihan percakapan) dan munhâdarah (latihan pidato)." ${ }^{45}$

Wajib bahasa yang diterapkan di pesantren ini menjadikan bahasa Arab dengan kaidah tata bahasa yang rumit dan perubahan kata yang bervariasi tidak dianggap sebagai mata pelajaran yang sulit dan kurang diminati oleh santri. Sebab santri telah terbiasa mendengar, mengucapkan, membaca dan menulis menggunakan bahasa Arab.

Bahasa Arab bagi santri Madinatunnajah bukan lagi menjadi bahasa asing, hal ini disebabkan pesantren ini telah membudayakan bahasa Arab menjadi bahasa percakapan sehari-hari (muhâadatsah yawmîyah)denganlingkunganbahasabuatan (al-bî'ah al-lughawîyah al-ișthinâ îyah) yang mendukung. Sehingga tujuan pembelajaran bahasa yang sejatinya adalah untuk berkomunikasi telah tercapai dengan sistem pembelajaran wajib berbahasa Arab dalam percakapan sehari-hari yang ditetapkan di lingkungan tersebut.

45 Berdasarkan wawancara peneliti kepada Ustadzah Masyitah guru bahasa Arab dan Fiqih dan merupakan lulusan Universitas AL-Azhar, Cairo di pesantren Madinatunnajah Jombang-Ciputat, Tangerang Selatan pada 09 Januari 2016. 
Berikut adalah hasil penelitian di Pesantren ini yang ditampilkan secara ringkas:

\section{Keterampilan Menyimak}

\begin{tabular}{|c|c|c|c|c|c|c|}
\hline \multirow{2}{*}{ Model } & $\mathrm{R}$ & $\mathrm{R}$ & $\begin{array}{c}\text { Adjusted } \\
\text { Square }\end{array}$ & $\begin{array}{c}\text { Std. Error } \\
\text { of the } \\
\text { R Square } \\
\text { Estimate }\end{array}$ & $\begin{array}{c}\text { Ch Square } \\
\text { Change }\end{array}$ & $\begin{array}{c}\mathrm{F} \\
\text { Change }\end{array}$ \\
\hline 1 &, $871 \mathrm{a}$ &, 759 &, 756 & 2,67687 &, 759 & 239,238 \\
\hline
\end{tabular}

\begin{tabular}{|c|c|c|c|}
\hline \multicolumn{4}{|c|}{ Model Summary ${ }^{\mathrm{b}}$} \\
\hline \multirow{2}{*}{ Model } & \multicolumn{3}{|c|}{ Change Statistics } \\
\hline & df1 & $\mathrm{df} 2$ & Sig. F Change \\
\hline 1 & 1 & 76 & ,000 \\
\hline
\end{tabular}

a. Predictors: (Constant), LINGKUNGAN ARTIFISIAL

b. Dependent Variable: MAHIR MENYIMAK

Pada tabel Model Summary di atas diperoleh koefisien determinasi dari regresi ganda [R Square] $\mathrm{R}^{2}=0,759$. Dengan kata lain, sebesar 75,9 \% lingkungan artifisial berhubungan kuat dengan kemahiran menyimak. Pada kolom Sig. F Change diperoleh Sig. $=0,000$. Karena $\alpha=0,05>$ Sig. $=0,000$ maka $\mathrm{H}_{0}$ ditolak dan $\mathrm{H}_{\mathrm{a}}$ diterima. Dengan kata lain, lingkungan artifisial berhubungan linier dengan kemahiran menyimak.

Menyimak adalah kegiatan reseptif selain membaca, artinya keterampilan menyimak tetap merupakan keterampilan paling penting yang harus diajarkan kepada siswa sebelum menguasai keterampilan berbicara, membaca dan menulis. Menurut Ustadzah Masyithah, guru di pesantren ini, bahwa kemahiran menyimak siswa sudah dikatakan baik, karena siswa telah dibiasakan untuk mendengar pengumumanpengumuman berbahasa Arab, penjelasan materi berbahasa Arab dan saling bertanya jawab menggunakan bahasa Arab. Sehingga hasil tes kemahiran menyimak siswa Madinatunnajah telah dikatakan berhasil dengan nilai rata-rata $=80,32$ dengan KKM 75. Besar pengaruh lingkungan artifisial terhadap kemahiran menyimak adalah $75,9 \%$ dengan persentase sebesar 24,1\% dipengaruhi oleh faktor lain.

\section{Keterampilan berbicara}

\begin{tabular}{|c|c|c|c|c|c|c|}
\hline \multirow{2}{*}{ Model } & \multirow{2}{*}{ M } & \multirow{R}{*}{$\begin{array}{c}\text { Model Summary } \\
\text { Square }\end{array}$} & $\begin{array}{c}\text { Adjusted } \\
\text { R Square }\end{array}$ & $\begin{array}{c}\text { Std. Error } \\
\text { of the } \\
\text { Estimate }\end{array}$ & $\begin{array}{c}\text { Change Statistics } \\
\text { Change }\end{array}$ & $\begin{array}{c}\text { F } \\
\text { Change }\end{array}$ \\
\hline 1 &, $901 \mathrm{a}$ &, 812 &, 810 & 2,12072 &, 812 & 328,758 \\
\hline
\end{tabular}

\begin{tabular}{|c|c|c|c|}
\multicolumn{4}{c|}{ Model Summary $^{\mathbf{b}}$} \\
\hline \multirow{2}{*}{ Model } & \multicolumn{3}{|c|}{ Change Statistics } \\
\cline { 2 - 4 } & df1 & df2 & Sig. F Change \\
\hline 1 & 1 & 76 &, 000 \\
\hline
\end{tabular}

a. Predictors: (Constant), LINGKUNGAN ARTIFISIAL

b. Dependent Variable: MAHIR BICARA

Pada tabel Model Summary di atas, diperoleh koefisien determinasi dari regresi ganda [R Square] $\mathrm{R}^{2}=0,812$. Dengan kata lain, sebesar 81,2 \% lingkungan artifisial berkorelasi kuat dengan kemahiran berbicara. Pada kolom Sig. F Change diperoleh Sig. $=0,000$. Karena $\alpha=0,05>$ Sig. $=0,000$ maka $\mathrm{H}_{0}$ ditolak dan $\mathrm{H}_{\mathrm{a}}$ diterima. Dengan kata lain, lingkungan artifisial berhubungan linier dengan kemahiran berbicara.

Pengaruh lingkungan artifisial terhadap kemahiran berbicara siswa cukup tinggi dengan perolehan sebesar 81,2 \%. Artinya hubungan antara lingkungan artifisial dengan kemahiran berbicara sangat signifikan dengan persentase di atas $75 \%$. Lingkungan memang sangat mempengaruhi seseorang dalam berbahasa, khususnya secara lisan.

Kemahiran berbicara yang diperoleh oleh siswa Madinatunnajah dipengaruhi oleh lingkungan bahasa yang diciptakan di pesantren tersebut. Menurut Ahmad Zaki Ramadhan siswa kelas XI, lingkungan di pesantren Madinatunnajah mendukung siswa untuk berbahasa Arab. Meskipun kemudian Ahmad Zaki menyatakan bahwa, "penggunaan bahasa selayaknya didukung 
oleh para guru yang juga aktifmenggunakan bahasa agar siswa semakin termotivasi".

Pengaruh lingkungan artifisial terhadap kemahiran berbicara dengan persentase $81,2 \%$ perolehan yang cukup tinggi. Sehingga dapat disimpulkan secara general bahwa kemahiran berbahasa dipengaruhi oleh faktor lingkungan artifisial yang diciptakan di pesantren tersebut dan sebanyak 18,8\% dipengaruhi oleh faktor lain.

Faktor lain yang mempengaruhi kemampuan siswa terbagi pada faktor internal dan eksternal. Dimyati dan Mujiono menjelaskan bahwa faktor penting yang mempengaruhi kemahiran siswa dalam berbicara menggunakan bahasa Arab terbagi pada dua yaitu faktor internal dan eksternal. Faktor internal meliputi motivasi, latar belakang, usia dan jenis kelamin. Adapun faktor eksternal mencakup guru, sarana prasarana, materi pengajaran dan lingkungan. ${ }^{46}$

Berdasarkan hasil wawancara ustadzah Romlah, guru bahasa Arab di pesantren ini, menyatakan bahwa, "Kesulitan yang dihadapi pengajar dalam menerapkan bahasa di pesantren ini di antaranya faktor dari siswa sendiri, seperti latar belakang pendidikan yang berbeda".

Hasil wawancara peneliti dengan satu siswa, Ahmad Zaki Ramadhan, menyatakan "penggunaan bahasa selayaknya didukung oleh para guru yang juga aktifmenggunakan bahasa agar siswa semakin termotivasi".

Cara ini merupakan bagian terdasar yang mungkin jarang dilakukan oleh para pengajar yaitu dengan memberikan contoh sebagai media pembelajaran yang baik bagi siswa. ${ }^{47}$ Faktor lain yang juga cukup

46 Dimyati dan Mujiono, Belajar dan Pembelajaran (Jakarta: Rineka Cipta, 1999), h. 248253. penting menurut peneliti adalah motivasi. Motivasi menjadi faktor paling berpengaruh sebab ia hadir dari dalam jiwa seseorang. Bagaimanapun lingkungan dibentuk untuk memberikan stimulus yang kuat dalam membangun kemampuan berbahasa, jika pembelajar bahasa tidak memiliki ketertarikan maka respon yang dilakukan akan berbeda dengan seseorang yang memiliki motivasi tinggi dalam mempelajari bahasa asing.

\section{Keterampilan Membaca}

\begin{tabular}{|c|c|c|c|c|c|c|}
\hline \multirow[b]{3}{*}{ Model } & & & Todel Sum & mary ${ }^{a}$ & & \\
\hline & \multirow[b]{2}{*}{$\mathrm{R}$} & \multirow[b]{2}{*}{$\begin{array}{c}\mathrm{R} \\
\text { Square }\end{array}$} & \multirow[b]{2}{*}{$\begin{array}{l}\text { Adjusted } \\
\text { R Square }\end{array}$} & \multirow{2}{*}{$\begin{array}{l}\text { Std. Error } \\
\text { of the } \\
\text { Estimate }\end{array}$} & \multicolumn{2}{|c|}{ Change Statistics } \\
\hline & & & & & $\begin{array}{l}\text { R Square } \\
\text { Change }\end{array}$ & $\begin{array}{c}\mathrm{F} \\
\text { Change }\end{array}$ \\
\hline 1 & ,830a & ,689 & ,685 & 3,37612 & ,689 & 168,663 \\
\hline
\end{tabular}

\begin{tabular}{|c|c|c|c|}
\multicolumn{4}{c|}{ Model Summary } \\
\hline \multirow{2}{*}{ Model } & \multicolumn{3}{|c|}{ Change Statistics } \\
\cline { 2 - 4 } & df1 & df2 & Sig. F Change \\
\hline 1 & 1 & 76 &, 000 \\
\hline
\end{tabular}

a. Predictors: (Constant), LINGKUNGAN ARTIFISIAL

b. Dependent Variable: MAHIR MEMBACA

Pada tabel Model Summary di atas, diperoleh koefisien determinasi dari regresi ganda [R Square] $\mathrm{R}^{2}=0,689$. Dengan kata lain, sebesar 68,9 \% lingkungan artifisial berhubungan kuat dengan kemahiran membaca. Pada kolom Sig. F Change diperoleh Sig. $=0,000$. Karena $\alpha=0,05$ Sig. $=0,000$ maka $\mathrm{H}_{0}$ ditolak dan $\mathrm{H}_{\mathrm{a}}$ diterima. Dengan kata lain, lingkungan artifisial berkorelasi linier dengan kemahiran membaca.

Tingkat kemahiran membaca siswa Mainatunnajah mengalami penurunan dibanding dengan kemahiran menyimak dan berbicara dengan persentase sebesar $68,9 \%$. Menurut peneliti, salah satu penyebabnya adalah bahwa siswa lebih aktif dalam menyimak dan berbicara namun tidak lebih aktif dalam membaca. Kemahiran membaca siswa Madinatunnjah

(Semarang: Rasail, 2005), h. 131-132. 
sebenarnya sudah cukup baik berdasarkan hasil tes yang peneliti berikan kepada siswa dengan rata-rata nilai 85,87 dengan KKM 75. Artinya, kemahiran membaca siswa telah dapat dikatakan berhasil jika menggunakan standar kelulusan yang berlaku dengan rata-rata nilai minimal 75 .

Kemahiran membaca tersebut salah satunya dipengaruhi oleh lingkungan pandang baca yang baik. Lingkungan pandang baca yang diterapkan di pesantren ini secara langsung memberikan stimulus kepada seluruh siswa untuk membaca bahasa Arab. Seperti papan kosakata, penulisan mading, tulisan-tulisan atau motto berbahasa Arab dan lingkungan pandang baca yang diterapkan berupa penulisan kosakata yang ditempelkan di beberapa lokasi di sekitar pesantren. Dapat disimpulkan bahwa lingkungan merupakan faktor yang cukup berpengaruh secara signifikan bagi kemahiran membaca bahasa Arab siswa.

Meskipun tidak terbukti memberikan pengaruh sebesar $100 \%$, namun perolehan sebesar 68,9 \% sudah cukup signifikan. Artinya, kemahiran membaca siswa sebagian besar sangat dipengaruhi oleh lingkungan pandang baca yang diciptakan secara artifisial.

\section{Keterampilan Menulis}

\begin{tabular}{|c|c|c|c|c|c|c|}
\hline & & & Model Sum & mary ${ }^{a}$ & & \\
\hline \multirow[b]{2}{*}{ Model } & \multirow[b]{2}{*}{$\mathrm{R}$} & \multirow{2}{*}{$\begin{array}{c}\mathrm{R} \\
\text { Square }\end{array}$} & \multirow{2}{*}{$\begin{array}{l}\text { Adjusted } \\
\text { R Square }\end{array}$} & \multirow{2}{*}{$\begin{array}{c}\text { Std. Error } \\
\text { of the } \\
\text { Estimate }\end{array}$} & \multicolumn{2}{|c|}{ Change Statistics } \\
\hline & & & & & $\begin{array}{c}\text { R Square } \\
\text { Change } \\
\end{array}$ & $\begin{array}{c}\mathrm{F} \\
\text { Change }\end{array}$ \\
\hline 1 & ,726a &, 527 &, 520 & 4,77037 &, 527 & 84,526 \\
\hline
\end{tabular}

\begin{tabular}{|c|c|c|c|}
\multicolumn{4}{c}{ Model Summary $^{\mathbf{b}}$} \\
\hline \multirow{2}{*}{ Model } & \multicolumn{3}{|c|}{ Change Statistics } \\
\cline { 2 - 4 } & df1 & df2 & Sig. F Change \\
\hline 1 & 1 & 76 &, 000 \\
\hline
\end{tabular}

a. Predictors: (Constant), LINGKUNGAN ARTIFISIAL

b. Dependent Variable: MAHIR MENULIS

Pada tabel Model Summary di atas, diperoleh koefisien determinasi dari regresi ganda [R Square] $\mathrm{R}^{2}=0,527$. Dengan kata lain, sebesar 52,7 \% lingkungan artifisial berkorelasi kuat dengan kemahiran membaca. Pada kolom Sig. F Change diperoleh Sig. $=0,000$. Karena $\alpha=0,05$ Sig. = 0,000 maka $\mathrm{H}_{0}$ ditolak dan $\mathrm{H}_{\mathrm{a}}$ diterima. Dengan kata lain, lingkungan artifisial berhubungan linier dengan kemahiran menulis.

Kemahiran menulis merupakan kegiatan produktif selain berbicara. ${ }^{48}$ Menulis menjadi salah satu kemahiran yang paling sulit bagi siswa, sebab menulis tidak hanya melibatkan otak, mata dan mulut seperti dalam kegiatan berbicara dan membaca dan melibatkan otak, mata dan telinga seperti dalam kegiatan menyimak. Kegiatan menulis menjadi lebih kompleks dengan melibatkan otak, mata, dan juga tangan untuk menciptakan sebuah pesan berupa tulisan yang dapat dipahami.

Kemahiran menulis di pesantren Madinatunnajah berkaitan erat dengan (pelajaran Insyâ' الإنشـاء) yang merupakan pelajaran mengarang berbahasa Arab. Pelajaran ini secara langsung melibatkan kecerdasan otak dalam mengolah bahasa menjadi kalimat berbahasa Arab yang tepat. Selain harus benar-benar memahami perbedaan huruf tunggal, huruf tengah dan huruf akhir, siswa juga harus memahami kaidah bahasa Arab dengan benar agar dapat membedakan kata ganti dalam bahasa Arab (mudhakkar dan mu'annath), kata kerja (fi't), kata benda (ism) dan seterusnya, sehingga kemampuan berbahasa Arab yang begitu kompleks menjadi salah satu problem mengapa menulis berbahasa Arab menjadi satu kesulitan tersendiri bagi siswa baik yang berada di tingkat rendah, menengah hingga tinggi.

${ }^{48}$ Ahmad Fuad Effendy, Metodologi Pengajaran Bahasa Arab, h. 78. 
Rendahnya kemampuan siswa Madinatunnajah dalam menulis terbukti dari nilai rata-rata berdasarkan hasil tes yang diberikan kepada siswa yaitu 72,67 dengan KKM 75. Artinya kemahiran menulis siswa masih cukup rendah dan berada di bawah KKM dibanding dengan kemahiran menyimak dengan nilai rata-rata $=80,03$. Kemahiran Berbicara $=81,75$ dan kemahiran membaca $=85,87$ dan berada di atas KKM.

Menurut ustadzah Masyithah, "Jika berbicara bahasa Arab, siswa bisa dikatakan mahir, namun ketika menulis kebanyakan siswa tidak bisa sebab mereka hanya mengucapkan tanpa tau tulisan".49

Menurut peneliti, meningkatkan kemahiran menulis selain dengan melatih siswa menulis berbahasa Arab (mengarang) juga perlu adanya pelatihan dari pengajar secara berkesinambungan. Kebiasaan menulisberbahasaArabyangdilakukanterusmenerus baik di kelas saat pembelajaran maupun di luar kelas seperti penulisan majalah dinding berbahasa, penulisan puisi, pidato, makalah dan menulis cerita pendek berbahasa Arab dengan bimbingan yang tepat dari pengajar maupun bagian bahasa akan memberikan pengaruh yang signifikan.

Kelemahan siswa dalam menulis salah satunya disebabkan oleh kurangnya pengawasan pengajar. Pengawasan yang tepat dari pengajar akan meningkatkan kemampuan siswa dalam menulis secara perlahan. Pelajar tidak hanya mengucapkan kalimat bahasa Arab tanpa mengerti bagaimana cara menulis yang benar berdasarkan kaidah.

Latihan menulis secara terus menerus dengan pengawasan yang tepatdari pengajar bukan merupakan hal yang mudah jika tidak dilakukan dengan niat untuk benar-benar

49 Berdasarkan wawancara dengan ustadzah Masyithah di Pondok Pesantren Madinatunnajah, pada 1 Juni 2016. meningkatkan kemahiran menulis siswa. Ketekunan dari siswa untuk menulis dan kesabaran dari pengajar harus seimbang, sehingga tujuan kemahiran menulis akan tercapai. Selain memberikan tugas menulis kepada siswa dengan pengawasan yang tepat, pengajar juga harus memberikan motivasi agar keinginan untuk mahir menulis dapat hadir dari dalam diri siswa secara sadar.

Motivasi yang tinggi dari dalam diri siswa akan menyebabkan siswa memiliki keinginan kuat untuk mau melakukan keinginannya tanpa paksaan dari luar, sehingga pengajar hanya melibatkan diri sebagai pengawas dan media yang baik tanpa memaksa siswa untuk menulis dan menjadi mahir.

Lingkungan bahasa artifisial yang diciptakan di pesantren ini menurut peneliti telah cukup baik dalam meningkatkan kemahiran berbahasa Arab siswa meskipun tidak total. Lingkungan bicara mampu meningkatkan kemahiran berbicara sebesar 81,2\%. Lingkungan pandang baca mampu meningkatkan kemahiran membaca sebesar $68,9 \%$ dan lingkungan pandang dengar yang meningkatkan kemahiran menyimak sebesar $75,9 \%$.

Persentase tersebut cukup tinggi dibanding kemahiran menulis siswa yang hanya sebesar 52,7\%. Artinya, sebesar 47,3\% kemahiran menulis siswa Madinatunnajah dipengaruhi oleh faktor lain. Persentase ini menurut peneliti masih dikatakan belum berhasil, terlebih lagi hasil tes menulis yang diberikan kepada siswa hanya memperoleh nilai rata-rata sebesar 72,67.

Namun jika penciptaan lingkungan bahasa artifisial di pesantren ini dilakukan lebih baik lagi seperti dengan menambah beberapa media inovasi yang lebih mendukung terhadap kemahiran siswa, 
maka kemungkinan besar kemahiran siswa akan mengalami kenaikan perolehan hasil yang lebih tinggi. Seperti pada kegiatan mengarang mingguan (Insyâ' Usbû'i) yang dilakukan setiap hari Jum'at oleh bagian bahasa yang diwajibkan kepada seluruh siswa Madinatunnajah yang menurut peneliti sudah cukup baik untuk meningkatkan kemampuan menulis siswa.

Kegiatan mengarang mingguan tersebut menurut peneliti harus mendapatkan pengawasan lebih baik lagi dari pengajar agar kemahiran menulis siswa dapat terkontrol dengan baik dan untuk mengetahui sejauh mana perkembangan menulis bahasa Arab siswa. Wadah yang diberikan kepada siswa harus berada di bawah pengawasan siswa dengan memberikan penguatan (reinforcement) seperti yang diungkapkan oleh B.F. Skinner dalam teori Stimulus-Respon-Penguatan, bahwa dalam pembelajaran dibutuhkan sebuah proses yang dilakukan terus menerus dengan memberikan stimulus dan penguatan atas respon dari pembelajar. Proses pembelajaran tersebut tentunya membutuhkan sebuah lingkungan yang mendukung, sebab lingkungan merupakan faktor penting dalam pemerolehan dan pembelajaran bahasa. ${ }^{50}$

Kemahiran menulis merupakan kemahiran keempat setelah kemahiran menyimak, berbicara dan membaca yang juga harus dikuasai oleh siswa. Keterampilan menulis merupakan keterampilan akhir yang paling sulit. Selain harus menguasai kaidah penulisan huruf hijaiyah, menulis bahasa Arab juga harus menguasai kaidah bahasa Arab yang benar. Salah satu problem dalam menulis bahasa Arab adalah susunan kata yang berbeda dengan bahasa Indonesia,

50 John A. Nevin, "Burrhus Frederic Skinner: 1904-1990", The American Journal of Psychology, Vol. 105, No. 4, (Winter, 1992), h. 613-619. sehingga siswa harus benar-benar paham ilmu Nahww dan Șaraf.

Pemecahan masalah yang dapat dilakukan misalnya dengan memberikan tugas mengarang kepada siswa dengan tema bebas atau tema yang telah ditentukan oleh pengajar. Kemudian siswa membacakan tulisannya masing-masing di depan temanteman di kelas. Sehingga para siswa diberi kesempatan untuk mengoreksi kesalahan temannya dan memberikan masukan yang benar. Cara ini akan mengaktifkan siswa ketika pembelajaran di kelas dengan mengajak siswa untuk menyimak kesalahan siswa lain.

Selanjutnya pengajar juga bisa mengelompokkan siswa menjadi beberapa kelompok dengan memberikan tugas pembuatan cerpen atau redaksi berbahasa Arab. Tugas tersebut kemudian ditempelkan di mading sekolah untuk dibaca oleh seluruh siswa. Sehingga secara tidak langsung kegiatan tersebut dapat meningkatkan kemahiran menulis sekaligus membaca siswa.

\section{Analisis Pengaruh Lingkungan Bahasa Artifisial terhadap Keterampilan Berbahasa Arab Siswa}

Setelah diperoleh hasil pengaruh terhadap empat keterampilan berbahasa di atas, selanjutnya disajikan hasil pengaruh berdasarkan hasil hitung Variabel X (Lingkungan Artifisial) dan Variabel Y (Kemahiran Berbahasa Arab) menggunakan SPSS sebagai berikut:

\begin{tabular}{|c|c|c|c|}
\hline \multicolumn{4}{c|}{ Variables Entered/Removed $^{\mathbf{a}}$} \\
\hline Model & Variables Entered & $\begin{array}{c}\text { Variables } \\
\text { Removed }\end{array}$ & Method \\
\hline 1 & $\begin{array}{c}\text { LINGKUNGAN } \\
\text { ARTIFISIAL }^{\mathrm{b}}\end{array}$ & $\cdot$ & Enter \\
\hline
\end{tabular}
a. Dependent Variable: KEMAHIRAN BERBAHASA
b. All requested variables entered 
Model Summary

\begin{tabular}{|c|c|c|c|c|c|c|}
\hline \multirow[b]{2}{*}{ Model } & & \multirow{2}{*}{$\begin{array}{c}\mathrm{R} \\
\text { Square }\end{array}$} & \multirow{2}{*}{$\begin{array}{l}\text { Adjusted } \\
\text { R Square }\end{array}$} & \multirow{2}{*}{$\begin{array}{l}\text { Std. Error } \\
\text { of the } \\
\text { Estimate }\end{array}$} & \multicolumn{2}{|c|}{ Change Statistics } \\
\hline & & & & & $\begin{array}{l}\text { R Square } \\
\text { Change }\end{array}$ & $\begin{array}{c}\mathrm{F} \\
\text { Change }\end{array}$ \\
\hline 1 & $927 \mathrm{a}$ & ,859 & ,857 & 1,94887 & ,859 & 462,049 \\
\hline
\end{tabular}

Model Summary ${ }^{b}$

\begin{tabular}{|c|c|c|c|}
\hline \multirow{2}{*}{ Model } & \multicolumn{3}{|c|}{ Change Statistics } \\
\cline { 2 - 4 } & df1 & df2 & Sig. F Change \\
\hline 1 & 1 & 76 &, 000 \\
\hline
\end{tabular}

\section{ANOVA $^{\mathrm{a}}$}

\begin{tabular}{|l|c|c|c|c|c|}
\hline Model & $\begin{array}{c}\text { Sum of } \\
\text { Squares }\end{array}$ & $\mathrm{df}$ & $\begin{array}{c}\text { Mean } \\
\text { Square }\end{array}$ & $\mathrm{F}$ & Sig. \\
\hline 1. Regression & 1754,900 & 1 & 1754,900 & 462,049 &, $000 \mathrm{~b}$ \\
\hline 2. Residual & 288,654 & 76 & 3,798 & & \\
\hline Total & 2043,554 & 77 & & & \\
\hline
\end{tabular}

a. Dependent Variable: KEMAHIRAN BERBAHASA

b. Predictors: (Constant), LINGKUNGAN ARTIFISIAL

Coefficients $^{\mathrm{a}}$

\begin{tabular}{|l|c|r|r|}
\hline \multirow{2}{*}{ Model } & \multirow{2}{*}{ Sig. } & \multicolumn{2}{|c|}{$95.0 \%$ Confidence Interval for B } \\
\cline { 3 - 4 } & & Lower Bound & \multicolumn{1}{c|}{ Upper Bound } \\
\hline 1. (Constant) &, 000 & 8,538 & 20,705 \\
\hline LINGKUNGAN &, 000 & 1,180 & 1,421 \\
ARTIFISIAL & & & \\
\hline
\end{tabular}

\section{Coefficients $^{\mathrm{a}}$}

\begin{tabular}{|c|c|c|c|c|}
\hline \multirow[t]{2}{*}{ Model } & \multicolumn{2}{|c|}{$\begin{array}{c}\text { Unstandardized } \\
\text { Coefficients } \\
\end{array}$} & \multirow{2}{*}{$\begin{array}{c}\text { Standardized } \\
\text { Coefficients }\end{array}$} & \multirow[t]{2}{*}{$\mathrm{t}$} \\
\hline & B & Std. Error & & \\
\hline 1. (Constant) & 14,622 & 3,054 & & 4,787 \\
\hline $\begin{array}{l}\text { LINGKUNGAN } \\
\text { ARTIFISIAL }\end{array}$ & 1,300 & ,060 & ,927 & 21,495 \\
\hline
\end{tabular}

\section{Interpretasi Data}

Data Y (Kemahiran Berbahasa) diperoleh berdasarkan seluruh data kemahiran menyimak, kemahiran berbicara, kemahiran membaca dan kemahiran menulis yang dikorelasikan dengan variabel $\mathrm{X}$ (Lingkungan Artifisial) untuk mengetahui seberapa besar pengaruh Variabel $X$ terhadap Variabel Y secara keseluruhan.

Berdasarkan tabel Model Summary, diperoleh koefisien determinasi dari regresi ganda [R Square] $\mathrm{R}^{2}=0,859$. Dengan kata lain, sebesar 85,9 \% lingkungan artifisial berhubungan kuat dengan kemahiran berbahasa Arab. Artinya, pengaruh lingkungan artifisial di pesantren ini terhadap kemahiran berbahasa Arab telah dapat dikatakan berhasil karena tingkat persentase berada di atas $75 \%$. Persentase di atas menurut peneliti cukup tinggi dan signifikan. 85,9 \% kemahiran berbahasa Arab siswa dipengaruhi oleh lingkungan artifisial, dengan kata lain 14,1 $\%$ dipengaruhi oleh faktor lain.

Faktor lain tersebut menurut peneliti dipengaruhi oleh latar belakang pendidikan siswa kelas X dan XI yang sebagian besar adalah siswa lulusan MTs, sehingga pendidikan bahasa Arab siswa kelas X dan XI telah cukup memadai berdasarkan pada kemampuan bahasa Arab yang diperoleh saat berada di jenjang MTs.

Faktor selanjutnya adalah motivasi dan minat siswa yang tinggi dalam mempelajari bahasa Arab. Hal ini terlihat dari keaktifan siswa menggunakan bahasa Arab dalam percakapan sehari-hari dan kegiatankegiatan kebahasaan yang diikuti oleh siswa dengan penuh semangat. Motivasi dan minat yang tinggi menurut peneliti adalah faktor berpengaruh yang harus dimiliki oleh pelajar untuk mencapai tujuan pembelajaran.

Lingkungan bahasa yang diciptakan dengan motivasi dan minatyang tinggi dalam belajar bahasa Arab akan menghasilkan korelasi positif yang signifikan. LAD yang merupakan perangkat akuisisi bahasa bawaan sejak lahir akan semakin kompleks dengan lingkungan bahasa yang diciptakan sebagai wadah untuk proses pembelajaran.

Lingkungan artifisial di pesantren ini terbukti mampu mempengaruhi kemahiran berbahasa Arab siswa, salah satunya karena sistem wajib bahasa yang diterapkan di pesantren tersebut. Selain wajib bahasa, 
beberapa faktor yang mempengaruhi kemahiran berbahasa Arab siswa berdasarkan hasil penelitian, di antaranya:

\section{Pengawasan dan penguatan (reinforcement) yang tepat}

Pengawasan dan penguatan (reinforcement) yang tepat dari pengajar dan penggerak bahasa merupakan salah satu faktor mengapa lingkungan artifisial yang diterapkan di pesantren ini berhasil memahirkan siswa dalam menyimak, berbicara, membaca dan menulis bahasa Arab. Stimulus yang diberikan oleh para pengajar kepada siswa dalam menciptakan lingkungan bahasa artifisial yang kemudian direspon oleh siswa dengan tertib menggunakan bahasa Arab dalam percakapan sehari-hari ternyata tidak dilepaskan tanpa pengawasan begitu saja oleh pengajar.

Siswa yang berbicara menggunakan bahasa Arab dalam percakapan sehari-hari, tetap berada di bawah pengawasan para guru. Ketika siswasalah dalam menggunakan kaidah, maka guru atau penggerak bahasa akan menegur dan memberitahukan jawaban yang benar. Cara ini, menurut teori Behaviorisme Skinner berupa pembiasaan dan penguatan yang dilakukan dalam suatu proses pembelajaran atau dikenal dengan S-R-R yaitu stimulus-respon-penguatan.

Stimulus yang diberikan oleh pengajar dan penggerak bahasa dalam menciptakan lingkungan bahasa artifisial kemudian mendapatkan respon dari siswa berupa sikap dalam menjalankan dan menaati peraturan yang berlaku seperti wajib bahasa, latihan pidato (muhâdạarah), pemberian kosakata (mufradât), latihan percakapan (muhâadatsah) dan penulisan Insyâ.'

Pengawasan dan penguatan tetap diberikan oleh pengajar dan penggerak bahasa kepada siswa seperti mendengarkan siswa ketika bercakap-cakap menggunakan bahasa Arab kepada sesama teman. Cara sederhana ini merupakan kunci sukses mahir berbahasa asing. Sebab, selain mewajibkan siswa berbahasa asing yang sedang dipelajari, mengawasi siswa dalam bertutur juga dapat menyebabkan siswa semakin terbiasa karena selalu berada di bawah bimbingan dan pengawasan.

\section{Sumber Daya Manusia (SDM) yang mendukung}

Penciptaan lingkungan artifisial tentu memerlukan SDM yang mendukung. Menurut Ahmad Fuad, salah satu strategi penting dalam menciptakan lingkungan bahasa artifisial adalah Sumber Daya Manusia (SDM) yang mendukung seperti pengajar bahasa asing atau orang yang mendukung terciptanya lingkungan bahasa artifisial. ${ }^{51}$ Seperti halnya penciptaan lingkungan bahasa di Madinatunnajah yang memiliki SDM cukup baik dan mendukung yang ditunjukkan oleh sikap para pemimpin dan pendiri pesantren untuk menciptakan lingkungan bahasa artifisial di Madinatunnajah.

Penciptaan lingkungan bahasa dalam suatu lembaga tentu bukan perkara mudah. Hal pertama yang harus dilakukan adalah keingingan dari pendiri suatu lembaga dalam menciptakan lingkungan tersebut menjadi lingkungan berbahasa asing. Jika pendiri suatu lembaga menginginkan terciptanya lingkungan berbahasa asing dalam komunikasi sehari-hari, maka para

${ }^{51}$ Ahmad Fuad, Metodologi Pengajaran Bahasa Arab, h. 168-171. Selanjutnya lihat Bushairi, "Takwîn al-Bî’ah al-Musâ'idah wa TaTwîruhâ fî Ta'lîm alLughah al-'Arabîyah", Makalah pada Pelatihan Intensifikasi Pembelajaran Bahasa Arab bagi Guru MA se-Jawa, Bali, dan Nusa Tenggara, STAIN Malang (23-3i Mei, 2001), h. 4-5. 
pengajar yang bergerak di dalamnya akan semakin mudah untuk meneruskan visi misi tersebut.

Selain keinginan untuk menciptakan sebuah lingkungan berbahasa, sikap konsisten dan komitmen yang kuat juga harus dimiliki oleh pemimpin dan para penggerak yang berkecimpung di dalamnya. Sebab konsistensi dapat mempertahankan tujuan tersebut sesuai dengan visi misi untuk menjadikan bahasa Arab sebagai bahasa komunikasi sehari-hari dalam lingkungan tersebut.

\section{Siswa Tidak Malu/Takut Salah}

Rasa malu atau rasa takut salah asing seringkali dirasakan oleh pelajar yang baru mempelajari bahasa asing. Rasa takut salah menjadi salah satu problem mengapa belajar bahasa asing menjadi semakin sulit dipahami. Selain karena akan menghambat kemampuan dalam mengeksplorasi diri, rasa takut salah juga menyebabkan pembelajar enggan ataupun malas dalam mempelajari bahasa asing. Problem tersebut sering diabaikan oleh para pengajar bahasa, yang hanya meningkatkan kualitas pembelajaran namun mengabaikan hal-hal mendasar yang dirasakan oleh pelajar seperti rasa malu dan takut salah berbahasa asing.

Pesantren yang menerapkan sistem wajib bahasa dalam percakapan sehari-hari ini, selain didukung oleh SDM yang aktif dan kompeten, pengawasan dan penguatan yang tepat, ternyata juga didukung oleh hal mendasar yang dimiliki oleh siswa yang menyebabkan mereka menjadi mahir berbahasa Arab yaitu tidak merasa malu dan takut salah dalam berbahasa Arab. Faktor ini menjadi sangat penting, sebab bagaimanapun lingkungan bahasa itu dibentuk jika rasa ingin tahu dan kepercayaan diri siswa dalam berbahasa tidak terbentuk maka pengajar akan susah untuk mengajak siswa berbahasa Arab dalam percakapan sehari-hari seperti yang telah dilakukan di pesantren ini.

Percaya diri dengan tidak merasa malu dan takut salah dalam berbahasa asing dapat ditumbuhkan dengan mulai berkomunikasi ringan kepada sesama teman ketika di kelas maupun di asrama. Membiasakan untuk memulai berbicara menggunakan bahasa asing akan mampu mengikis rasa malu dan takut salah. Rasa malu dan takut salah berkaitan erat dengan diciptakananya lingkungan berbahasa asing. Dengan mewajibkan seluruh siswa untuk berbahasa Arab, maka rasa malu akan hilang sebab seluruh komunitas telah menggunakan bahasa yang sama.

Berani berbicara di depan umum juga menjadi salah satu cara agar dapat terhindar dari rasa takut salah. Kemampuan menyampaikan pesan kepada khalayak ramai tersebut juga menjadi kunci bahwa untuk bisa berbahasa asing pelajar bahasa harus berani dan menghilangkan rasa malu. Berani berbicara menggunakan bahasa asing tanpa takut salah juga akan meningkatkan kepercayaan diri siswa, sebab ketika berbahasa asing siswa tidak akan merasa bahwa apa yang diucapkannya adalah sesuatu yang salah atau memalukan. Sehingga ketika salah pelajar tidak akan berhenti mencoba melainkan akan terus belajar dan memperkaya kemampuannya.

\section{Penerapan Wajib Bahasa dan Mahkamah Bahasa}

Penerapan wajib bahasa di pondok pesantren ini dan beberapa pondok modern lainnya menjadi salah satu ciri khas yang membedakannya dengan pesantren tradisional dan lembaga sekolah pada umumnya. Hampir seluruh pesantren 
modern di Indonesia mewajibkan seluruh siswanya untuk menggunakan bahasa Arab dan bahasa Inggris dalam percakapan sehari-hari yang diatur melalui pekan bahasa (usbû'al-'Lughah).

Wajib bahasa di pesantren modern bukan hanya menjadi mahkota pesantren melainkan juga merupakan bagian dari peradaban dunia pesantren yang selama ini terkesan tradisional dan tertutup. Dengan penetapan wajib bahasa Arab dan Inggris dalam percakapan sehari-hari, pesantrenpesantren modern bukan hanya mampu mencetak kader yang islami melainkan juga mencetak kader yang mampu berbahasa asing, berwawasan luas dan berfikir kritis.

Wajib berbahasa Arab dan Inggris di pesantren ini dalam percakapan seharihari juga bukan hanya sekedar kewajiban. Peraturan tersebut juga diiringi dengan sebuah wadah yang mengelola dan mengawasi perkembangan bahasa siswa tersebut yang disebut dengan mahkamah bahasa. Mahkamah bahasa dikelola oleh organisasi santri di bawah naungan pengajar dan pimpinan pesantren.

Mahkamah adalah badan tempat memutuskan hukum atas suatu perkara atau pelanggaran. Adapun mahkamah bahasa di pesantren merupakan badan tempat memutuskan hukum atas pelanggaran bahasa yang dilakukan oleh santri. Mahkamah bahasa bekerja jika siswa tidak menggunakan bahasa Arab dan Inggris pada minggu bahasa yang telah ditentukan. Dengan mahkamah bahasa, seluruh siswa akan merasa takut untuk tidak menggunakan bahasa Arab dan Inggris dalam percakapan sehari-hari, sehingga mahkamah bahasa disebut cukup signifikan dalam meningkatkan kesadaran dan kemampuan siswa dalam berbahasa asing.
Hal ini berdasarkan hasil angket yang disebarkan kepada 78 responden, bahwa sebagian besar siswa setuju jika mahkamah bahasa memberikan pengaruh yang signifikan terhadap kemahiran siswa dalam berbahasa. Artinya, bahwa penerapan wajib bahasa dan mahkamah bahasa di pondok pesantren cukup memberikan pengaruh positif yang signifikan terhadap kemahiran siswa dalam berbahasa asing. Sebab siswa pada akhirnya lebih memilih untuk menggunakan bahasa dan mengikuti semua peraturan kebahasaan daripada harus menerima konsekuensi berupa hukuman dari mahkamah bahasa.

Akhirnya, penciptaan lingkungan bahasa artifisial di pesantren ini bukan hanya sebagai lingkungan bahasa buatan yang diciptakan tanpa pengawasan dan efek jera yang diberikan kepada siswa. Lingkungan bahasa artifisial tidak hanya diciptakan sebagai wadah bagi siswa untuk mengeksplorasi kemampuan berbahasa yang dimiliki, melainkan juga sebagai wadah pembelajaran bahasa dengan ketentuan bahwa untuk menjadi mahir adalah dengan melakukan pembiasaan dan pengulangan. Sejatinya belajar bahasa adalah untuk berkomunikasi baik lisan maupun tulisan, sehingga lingkungan bahasa diciptakan sebagai wadah untuk belajar dan mengasah kemampuan berkomunikasi tersebut.

Bagaimanapun siswa diberikan teori bahasa dengan metode terbaik oleh pengajar ketika di kelas, namun jika tidak diberikan kesempatan untuk berkomunikasi layaknya penutur asli maka pengajar tidak akan mengerti sejauh mana kemampuan siswa tersebut. Dengan penciptaan lingkungan bahasa, pengajar akan semakin mudah memberikan pengajaran sebab siswa akan diajak langsung dalam mempraktikkan bahasa yang sedang dipelajari sehingga 
terciptalah pembelajaran langsung timbal balik antara pengajar dan siswa. Metode tersebut menurut peneliti lebih efektif dalam pembelajaran bahasa dan terbukti memberikan pengaruh positif yang signifikan dibandingkan hanya memberikan teori ketika di kelas namun tanpa penerapan langsung.

Meskipun kemudian timbul anggapan, bahwa bahasa Arab yang digunakan oleh santri-santri pesantren modern adalah bahasa Arab "pasaran" dengan logat dan rasa bahasa Indonesia. Namun, hal itu tidak dapat dimungkiri sebab lidah santri modern adalah lidah bahasa Indonesia atau bahasa daerahyangmerupakanbahasapertamadan bahasa ibunya. Dengan mempelajari bahasa Arab sebagai bahasa asing, maka mampu menggunakannya dalam percakapan sehari-hari serta mampu menuliskannya dalam bentuk cerita ataupun kalimat adalah bentuk keberhasilan sistem pembelajaran bahasa asing itu sendiri dalam suatu lembaga pendidikan di Indonesia.

\section{Simpulan}

Kemampuan berbahasa tidak hanya ditentukan oleh LAD (Language Acquisition Device) yang merupakan perangkat akuisisi bahasa bawaan sejak lahir, melainkan sangat dipengaruhi oleh lingkungan. Hal ini terbukti dari hasil penelitian di pondok pesantren Madinatunnajah, Jombang, Ciputat, Tangerang Selatan yang menerapkan pembelajaran bahasa berbasis lingkungan. Lingkungan bahasa artifisial yang diterapkan di pesantren ini terbukti memberikan pengaruh positif yang signifikan terhadap kemahiran menyimak, berbicara, membaca, dan menulis bahasa Arab siswa.

Pembelajaran bahasa Arab berbasis lingkungan terbukti berpengaruh positif yang signifikan terhadap kemahiran berbahasa Arab siswa karena adanya sebuah proses pembelajaran yang dilakukan secara terus menerus dan berulang-ulang. Belajar bahasa dengan menggunakannya langsung dalam percakapan sehari-hari menjadi kunci utama mahir berbahasa asing. Selain bersifat kontinuitas, beberapa faktor yang dapat mempengaruhi kemahiran berbahasa adalah sebagai berikut: memberikan pengawasan yang tepat kepada siswa dalam berbahasa Arab sehari-hari, menetapkan wajib bahasa melalui pekan bahasa, penerapan mahkamah bahasa, SDM yang mendukung, dan rasa tidak takut salah dan malu dalam berbahasa asing.

\section{Daftar Rujukan}

Abdul Aziz Usman, Fatimah. "Al-Bî'ah alTa'lîmîyah wa-al-Adâ' al-Lughawî bayn al-Naẓîyah wa-al-TaṬbîq", Markaz alMalik Abdullah bin 'Abd al-Aziz, Jâmi'at Ta'lifal-'Arabîyahli-al-'Ulumal-Mihnîyah (2014).

Abdul Majid, Abdul Aziz. Al-Lughat al'Arabîyah: Ușûluhâ al-Nafsîyah waTuruq Tadrîsihâ. Cairo: Dâr al-Ma'ârif, 1961.

Ahmad al-Khifaji, Abdul Husein. "Athar Anmûdhaj 'Araḍ Mauḍû' Aqsâm al-Fi'l fî Tahṣ̂il Talâmidhat al-Ṣaf al-Khâmis al-Ibtidâ'î fî Mâddah Qawâ'id al-Lughah al-Arabîyah", Majallat al-Fath, Kullîyat al-Tarbîyah al-Islâmîyah Jâmi'ah Diyâli, al-'Adad 54, 2013.

Al-Dîlamy, Țaha 'Ali Husain wa Sa'ad 'Abd al-Karîm al-wâ'ily. Ittijâhât Hadîthah fî tadrîs al-Lughah al-Arabîyah. Oman: Jidâr Maktab al 'Âlamy, 2009.

Ali Samman, Mahmud. Al-Taujîh fî Tadrîs al-Lughah al-Arabîyah. Cairo: Jâmi'ah TanṬa, 1983. 
Alkhasawneh, S., F. Abd. Rahman, A. F. bin M. Ayyub, dan A. Bin M. Daud. "The Effect of Arabic as First Language Web Based Teaching in Jordanian Basic School Student's Arabic Reading Comprehension Motivation", International Journal of Innovative Ideas (IJII) ISSN: 2232-1932, Vol. 12, No. 4 (Nov., 2012).

B. Vecchio, Frank. "The "Revolution" in Foreign Language Teaching", Improving College and University Teaching, Vol. 21, No. 2, Teaching the Humanities: Rose Windows of Academia, Spring, 1973.

Beckner, Clay, Richard Blythe, Joan Bybee, Morten H. Christiansen, William Croft, Nick C. Ellis, John Holland, Jinyun Ke, Diane Larsen-Freeman, Tom Schoenemann, "Language Is a Complex Adaptive System: Position Paper", Language Learning, 59: Suppl. 1, (December, 2009), 1.

Bushairi. “Takwîn al-Bî’ah al-Musâ'idah wa TaṬ̂îruhâ fî Ta'lîm al-Lughah al'Arabîyah", Makalah pada Pelatihan Intensifikasi Pembelajaran Bahasa Arab bagi Guru MA se-Jawa, Bali, dan Nusa Tenggara, STAIN Malang (23-31 Mei, 2001).

C. Ellis, Nick. "The Dynamics of Second Language Emergence: Cycles of Language Use, Language Change, and Language Acquisition", The Modern Language Journal, Vol. 92, No. 2 (Summer, 2008), 232-249.

Chaer, Abdul dan Agustina. Sosiolinguistik Perkenalan Awal. Jakarta: Rineka Cipta, 2010.

Chaer, Abdul. Psikolinguistik Kajian Teoritik. Jakarta: Rineka Cipta, 2009.

Chapelle, Carol. "The Relationship between Second Language Acquisition Theory and Computer-Assisted Language Learning", The Modern LanguageJournal, Vol. 93, (2009).

Chomsky, Noam. On Nature and Language. Cambridge: University Press, 2002.

D. Krasen, Stephen. "Formal and Informal Linguistic Environments in Language Acquisition and Language Learning", TESOL Quarterly, Vol. 10, No. 2 (Jun., 1976).

Dimyati dan Mujiono. Belajar dan Pembelajaran. Jakarta: Rineka Cipta, 1999.

Dulay, Heidi, Marina Burt and Stephen Krashen, Language Two. New York: Oxford University Press, 1982.

E. Snow, Catherine. "Mothers' Speech to Children Learning Language", Child Development, Vol. 43, No. 2 (Jun., 1972).

Effendy, Ahmad Fuad.MetodologiPengajaran Bahasa Arab. Malang: Misykat, 2005.

Ellis, Rod. "Second Language Learning and Second Language Learners: Growth and Diversity", TESL Canada Journal/Revue TESL Du Canada, Vol. 7, No. 1, (Nov, 1989).

Ellis, Rod. Understanding Second Language Acquisition. New York: Oxford University Press, 1985.

Hamalik, Oemar. Proses Belajar Mengajar. Jakarta: Bumi Aksara, 2005.

Hermawan, Acep. Metodologi Pembelajaran Bahasa Arab. Bandung: PT Remaja Rosdakarya, 2011.

Hildreth, Gertrude. "Learning a Foreign Language", The French Review, Vol. 31, No. 4 (Feb., 1958).

Jager, Gerhard and Robert van Rooij. "Language Structure: Psychological and Social Constraints", Synthese, Vol. 159, No. 1 (Nov., 2007). 
Kearney, Erin. "Cultural Immersion in the Foreign Language Classroom: Some Narrative Possibilities", The Modern LanguageJournal, Vol. 94, No. 2 (Summer 2010).

Khirma' Nayef wa 'Ali Hijaj. al Lughât alAjnabîyah: Ta'lîmuhâ wa Ta'allumuhâ (Kuwait: Âlim al Ma'rifah, 1988).

Kovach, Madeline. "An Active Language Teaching Method", The German Quarterly, Vol. 36, No. 3 (May, 1963).

Kristianty, Theresia. "Pandangan-Pandangan

Teoritis Kaum Behaviorisme tentang Pemerolehan Bahasa Pertama", Jurnal Pendidikan Penabur, No.06, Th.V, (Juni, 2006).

L. Sakai, Kuniyoshi. "Language Acquisition and Brain Development", Science, New Series, Vol. 310, No. 5749, System-Level Brain Development (Nov,. 4, 2005).

Larsen, Diane. "Recent Innovations in Language Teaching Methodology", Annals of the American Academy of Political and Social Science, Vol. 490, Foreign Language Instruction: A National Agenda (Mar., 1987).

Malone, Susan. "Theories and Research of Second Language Acquisition", SIL International MLE WS, (Bangkok, 2012).

Masri'ah. "Bî’ah 'Arabîyah: Pembentukan dan Peranannya dalam Pembelajaran Bahasa Arab", El-Ibtikar , Vol. 02, No. 02 (Des., 2013).

Mat Teh, Kamarul Shukri dan Mohamed Amin Embi. "The Correlation between Language Learning Strategies and Motivationin Arabic Language Learning", Jurnal Pendidik dan Pendidikan, Jil. 24 (2010).
Nevin, John A. "Burrhus Frederic Skinner: 1904-1990", The American Journal of Psychology, Vol. 105, No. 4, (Winter, 1992).

Nikitina, Larisa. "Creating an Authentic Learning Environment in the Foreign Language Classroom", International Journal of Instruction, Vol.4, No.1, (January 2011).

Oller, D. Kimbrough. "Noam Chomsky's Role in Biological Theory: A Mixed Legacy" Konrad Lorenz Institute for Evaluation and Cognition Research, Vol. 3, No. 4, (August, 2008).

Parret, Herman. "Noam Chomsky. Linguistics and Philosophy by F. Hiorth", Tijdschrift voor Filosofie, 38ste Jaarg., Nr. 2 (JUNI 1976).

S. Hendrickson, James. "Error Correction in Foreign Language Teaching: Recent Theory, Research, and Practice", The Modern Language Journal, Vol. 62, No. 8 (Dec., 1978), 387-398. Published by: Wiley, http://www.jstor.org/ stable/326176.

Sapir, Edward. "Language and Environment", American Anthropologist, New Series, Vol. 14, No. 2 (Apr. - Jun., 1912).

Sarip Hidayat, Nandang. "Problematika Pembelajaran Bahasa Arab" Jurnal Pemikiran Islam, Fakultas Tarbiyah dan Keguruan UIN SUSKA Riau, Vol. 37, No. 1 (januari-juni, 2012).

Sholihuddin, Ahmad. Belajar Bahasa Melalui Kesalahan Berbahasa. Kediri: STAIN Kediri Press, 2012.

Suharno dan Titin Fatimah. "Problematika Metodologis Sistem Pembelajaran Bahasa Arab di Pondok Pesantren Modern Al-Istiqamah (PPMI) 
Ngatabaru", Istiqra', Jurnal Penelitian Ilmiah, P3M STAIN Datokarama Palu, Vol. 1, No. 2, (Juli-Des., 2013).

Syukur, Fatah. Teknologi Pendidikan. Semarang: Rasail, 2005.

T. Skinner, Daniel. "The Learning of Languages", The Modern Language Journal, Vol. 30, No. 8 (Dec., 1946).

Țalâl Hasan, Ahmad wa Maheram Ahmad. "Ta'lîm al-Lughah al-'Arabîyah alTawâșilîyah li-al-Ṭullâb ghair alMuslimîn fî̀ Jâmi'ah Mâlîziyâ Klintan: al-Tajârib wa-al-Tahhdiyât", Prosiding Seminar Antarabangsa Pengajaran Bahasa Arab, Fakulti Pengajian Islam, Universiti Kebangsaan Malaysia (2011).
Taylor, Insup. Psycholinguistics: Learning and Using Language. Englewood Cliffts: Prentice Hall. Inc. 1990.

Wâfi, 'Abd al-Wâhid. Al-Lughah wa alMujtama'. Kairo: Dâr Nahdat Miṣr, 1971.

Zaid Ismail, Muhammad dan Daud Ismail. "Barnâmij al-Anghamâs (Immersion) Lughawîy fî Tahnsîn al-Mahârât alLughawîyah", Prosiding Seminar Pengajaran dan Pembelajaran Bahasa Arab, al Jâmi'ah al SulṬ̂an Zainal Âbidîn Trengganu, 2014. 